\title{
Sağlık İletişiminde Motivasyona Yönelik Bir Çaba: Öz Yeterlilik İnancının ve Kişilerin Diyete İkna Edilmesi Sürecinin Analizi
}

DOI: $10.26466 /$ opus.871362

\author{
Ayșe Müge Yazgan * \\ * Öğr. Gör. Dr., Marmara Üniversitesi, Yabancı Diller Yüksek Okulu, İstanbul/Türkiye \\ E-Posta: $\underline{\text { muge@marmara.edu.tr }}$ \\ ORCID: 0000-0002-5909-5791
}

\begin{abstract}
Öz
Etkin sağlık iletişimi ile bireyler için önleyici ve koruyucu sağllk çerçevesi çizilebileceği aşikârdır. Bu konjonktür içindeki kamu sağhlğ̆ın gözeten perspektif, henüz hastalık evresi başlamadan ülke ekonomisine büyük katkı să̆layacă̆ını göstermektedir. Bu araştırma, kişinin sağlıklı beslenmeye yönelik düşüncelerinin analizini yaparken, bu analiz perspektifinde kendisinin ĕ̆itiminin, yaşam koşullarının, hayat biçiminin de incelenmesini amaçlamaktadır. Bu araştırmanın örneklemi İstanbul ili Maltepe ilçesi Yalı mahallesi ve Kadıköy İlçesi Fenerbahçe mahallesinde yaşayan, olasıllksız örnekleme içinde kartopu yöntemi ile ulaşılmış 18 yaş üstü 24 erkek ve 76 kadın birey olarak toplam 100 kişiden oluşmaktadır. Araştırma, Marmara Üniversitesi Sağlık Bilimleri Enstitüsü Etik Kurulu'ndan izin alındıktan sonra 2020 yılı Eylül ve Aralık ayları arasında yapılmıştır. Araştırma, Kişisel bilgi formu, Diyet Öz etkinlik İnanç Ölçeği ve İkna Ölçeğinden oluşmaktadır. Bulgular ve tartışma bölümü sahadan elde edilen veriler sonucunda anket formunda yer alan sorular yüzde ve frekanslar hesaplanarak tablolar halinde özetlenmiştir. Araştırma deseni nicel araştırma üzerine yapılanmıştır. Bulgular ve tartışma bölümü bu sonuca göre oluşmuştur. Bu araştırmada kullanılan ölçeklerin güvenilirliği belirlemek amactyla Cronbach Alfa güvenirlik katsayısı kullanılmışıtır. Verilerin analizi SPSS 23.0 paket programında yapılmıştır. Sonuç olarak, eğitim düzeyinin, yaşın, yaşanılan yerin, mesleğin, medeni durumunun öz yeterlik ve ikna açısından anlamlı farklılık gösterdiği anlaşılmıştır.
\end{abstract}

Anahtar Kelimeler: Beslenme davranışı, ikna edici iletişim, kamu sağhı̆̆ı, koruyucu sağlık, motivasyon. 


\title{
An Effort for Motivation in Health Communication: An Analysis of Self-Efficacy Beliefs and Persuasion of People to Diet
}

\begin{abstract}
That a preventive and protective health framework can be established for individuals through effective health communication is obvious. The perspective dealing with public health within this conjuncture demonstrates that it will make a great contribution to the national economy before the disease phase starts. While this study makes an analysis on the person's thoughts about healthy nutrition, it also aims to examine them from the perspectives of their education, living conditions, and life style. The sample of this study consisted of a total of a 100 individuals, 24 men and 76 women over the age of 18 living in Maltepe-Yalı and Kadıköy-Fenerbahçe districts of İstanbul province who were reached over the snowball method in the non-probability sampling method. The research on the study was conducted from 2020 September to 2020 December after obtaining permission from the Marmara University Institute of Health Sciences Ethics Committee. The research consisted of the individual information form, Selfefficacy Belief Scale, Persuasion Scale. The results taken from the questionnaire were summed up in charts in percentage and in frequency calculations. The research design was based on quantitative method. Findings and discussion sections were written according to the results. Cronbach Alpha reliability coefficient was used to determine the reliability of the scales used in this study. The analysis of the data was done in the SPSS 23.0 package program. As a result, it is understood that education level, age, income level, profession, marital status differ significantly in terms of self-efficacy and persuasion.
\end{abstract}

Key Words: Feeding patterns, persuasive communication, state medicine, preventive health motivation. 


\section{Giriş}

İletişim kişilerarasında bilgi, duygu ve düşünce alışverişidir. Kanal arac1lığı ile kaynaktan giden mesajın anlaşılması sonucunda alıcıda etki yapmaktadır. Diğer bir deyişle gönderici olan kişinin bilinçli bir niyetle gönderdiği mesajların alıcıyı etkilemesi beklenmektedir. İletişim, İngilizce "communication" kelimesinden dilimize girmiştir. Türk Dil Kurumu sözlüğüne göre, iletişim duygu ve düşüncelerin akla uygun şekilde başkalarına aktarılması, bildirilmesi olarak tanımlanmaktadır. Bu ifadeden yola çıkarak iletişim becerisinin iletişim yeterliliğine dönüşümünün eğitimle mümkün olduğu görülmekte, öğrenilebilir ve geliştirilebilir beceri olarak tanımlanmaktadır. Herkes mesajı alır ancak farklı yorumlar çünkü algılar farklı çalışmaktadır. İletişimde en önemli unsur dinlemektir. Dinleyen kişinin ileti dakikliğinin önem kazandığı dinleme becerisinde vericinin de empatik iletişim kurması ve güven duygusunu verebilmek için yeterince açık olması önemlidir. İletişimde beden dili ve ses en önemli iki faktördür. Kişi kendini ne kadar saklamaya çalışsa da beden dili ve ses tonu kendisini ele vermektedir. Örneğin; daha önce karşılaşılmamış bir insanın bile telefondaki ses tonundan dahi sevinçli, üzüntülü, heyecanlı veya kaygılı olduğu rahatlıkla anlaşılabilmektedir. İletişim insanların birbirlerini anlamasını, sevgiyi öğrenmesini sağlamaktadır çünkü iletişim duygu ve düşüncelerde pozitif yönde ilerleme demektir aksi takdirde gürültü olarak adlandırılmaktadır. Mevlana'nın da dediği gibi aynı dili konuşanlar değil, aynı duyguları paylaşanlar anlaşmaktadır. Heinemann iletişimi iki veya daha fazla insan arasındaki duygu ve düşünce paylaşımı olarak görmektedir. Ortak anlayışta buluşmak ancak ortak sözler, semboller ve simgelerle mümkündür (Reddi, 2009, s.38-39). Ortak sözler etikettir. Krebs ve Davies (1993) için de iletişimin etkin yürümesi simge ve sembollerin doğru anlaşılması ile mümkündür. Dolayısı ile iletişim kişilerarasında bilgi paylaşımını sağlayan sosyal bir davranış olarak adlandırılmaktadır (Narula, 2006, s.5-6). İletişim sayesinde bilgi üretilmekte, anlamlandırılmakta ve çok daha önem verilerek paylaşılmaktadır (Dökmen, 2008, s.5561).

İletişimin en önemli parçası sosyalleşmedir. Sosyalleşmenin kuralı da sağliklı beşeri ilişkilerdir. Beşeri ilişkilerin ilerlemesi genellikle sofrada, 
yemek esnasında perçinleşmektedir. İş toplantıları, özel toplantılar, davetler ve organizasyonlar her zaman toplantı öncesinde veya sonrasinda yemek üzerine kuruludur. İçinden geçilen 2020 Covid 19 pandemi sürecinde bu tür etkinlikler askıya alınmış olsa da bu dönem, çekirdek ailenin sofralarında aile fertleri ile bir arada evde yemek yeme alışkanlıklarını, dengeli ve sağlıklı beslenmenin önemini bir kez daha ortaya koymaktadır.

Sağlıklı ve dengeli yemek yemek sağlıklı yaşam anlayışı diyerek günümüzde sağlık kavramı ve sağlıklı kalma perspektifi üzerine değişen hızlı koşullar oldukça önem kazanmıştır. Geçmişte beslenme adına yapılan hatalar tekrarlanmamaya çalışılmaktadır. Genç nesil fiziksel aktivitelerine yaşlı nesile göre daha fazla önem vermekte, sağlıklı beslenmek adına "yeni nesil mutfak" diye adlandırılan yemek türlerini denemektedir. Üç beyazdan imtina eden yeni nesil mutfak, un çeşitlerini, şeker miktarını ve türünü farklılaştırmakta, ağız tadını değiştirmektedir. Örneğin; beyaz un adı verilen buğday un yerine badem ya da ceviz unu tercih etmeye başlayan gençlik, şeker yerine de keçiboynuzu ya da hurma kullanmaktadır. Diğer bir deyişle sağlıklı kalmak için sağlıklı gıda tüketmek artık onlar için yeni bir yaşam felsefesi olmuştur. Sağlık kavramı kültürden kültüre, toplumların yaşadığı koşullara göre değişiklik göstermektedir. Dünya Sağlık Örgütü (DSÖ) ilk olarak 1948 yılında "Sağlık, sadece hasta ve sakat olmama durumu değil, aynı zamanda bedensel, ruhsal ve sosyal olarak tamamen rahat, iyilik içerisinde olma halidir" derken bu tanımla eleştiri almıştır (United Nations World Health Organization Interim Commision, 1948). Nedeni de sağlığın durağan değil dinamik olması vurgulanmamıştı. DSÖ, 1981'de "2000 Yılında Herkes için Sağlık” başlığındaki çalışmalar kapsamında, o dönemin ruhuna uygun bir biçimde, bir tanım daha yapt:: "Kendilerine sosyal ve ekonomik olarak üretken bir yaşam sürdürmeye olanak sağlayan sağlık düzeyi..." Bu saptamasıyla sağlık hizmetinin yalnızca üretim sürecindekilere yönelik olmasını dillendirdi. İlkine göre, çok daha geri düzeyde bir içerik ve hedefle ortaya çıkan bu yaklaşım birçok nedenden ötürü kabul görmedi ama bilelim ki DSÖ tarihinde böyle bir girişim yaşandı.

Terris (1995, s.3-5)'in sağlık kavram açısından incelendiğinde Dünya Sağlık Örgütüne katkı sağlamış olan Henry E. Sigerist'in sağlık anlayışını benimsediği anlaşılmaktadır. Terris'e göre, Sigerist sağlık içinde yeterli 
yaşam standardı bulunması gerektiğini vurgulamakta, sağlığın iyi olabilmesinin iyi çalışma koşulları ve sağlığı destekleyici eğitimle mümkün olacağını belirtmektedir. Raithel, Dollinger ve Hormann (2007) ise konuya üç tanımlama ile yaklaşmıştır:

1. Sınırlandırma: Bu kavram içerisinde hastalıkla ilgili tıbbi belirleme ve teşhis bağlantısına dayanmaktadır. Bu bağlamda sağlık, "hastalık durumu olmaması" olarak belirtilmektedir.

2. Özellikli sağlık: Bireyin çevre şartlarına uyumu üzerinde durulmaktadır. Diğger bir deyişle kişinin düşünceleri ile bedenen ve ruhen çevre koşullarına esnek bir biçimde adapte olması üzerinde durulmaktadır.

3. Yüksek değerli sağlık: Dünya Sağlık Örgütünün, “Sağlık, sadece hasta ve sakat olmama durumu değil, aynı zamanda bedensel, ruhsal ve sosyal olarak tamamen rahat, iyilik içerisinde olma halidir" tanımına uygunluğu göze çarpmaktadır.

Bireylerin hasta, hasta yakını veya potansiyel hasta adayı olarak görülmesi ile iletişim alanında yeni bir boyut ortaya çıkmıştır. Sağlık iletişimi olarak adlandırılan bu kavram 1970 li yıllarda ICA International Communication Association ile başlamıştır. 1985 yılında SCA Speech Communication Association komisyonunun kurulmasından sonra 1992 yılında bu iki dernek birleşmiş ve hem ulusal hem de uluslararası çalışmalarda hız kazanmıştır. Sağlık iletişimi içinde sadece sağlık bilimlerini değil aynı zamanda fen ve sosyal bilim dallarını da barındırmaktadır (Sabırcan, 2012, s.39). Sağlık iletişimi, sağlık psikolojisi, sağlık sosyolojisi, biyomedikal iletişim, davranışsal tıp, davranışsal sağlık ve tıbbi iletişim gibi yeni ortaya çıkan disiplinlerle birlikte gelişmektedir (Okay, 2016 a). Tarihsel süreç içerisinde Hipokrat, hastaların zor durumunda hekimin iyi niyetli yaklaşımı sayesinde kendilerinin sağlıklarına geri kavuşacaklarını belirtmektedir (Box, 2004, s.98). Sağlık iletişimi modern tıbbın ilerlemesi ile önem kazanmıştır. Bilimsel tıbbın ilerleme sürecinde duygular geri plana atılmıştır. Hasta ve hasta yakınları ile iletişimin zaruriyeti anlaşıldıkça hekim ile hasta arasında bağ kurulmaya başlanmıştır. Doktorun hastadan aldığı her bilgi, hasta üzerinde yaptığı her gözlem, uyguladığı her plan hastanın tedavisinde ve beraberce katettikleri yolda önemli bir gelişme sağlamaktadır. Hekimler halk dili ile daha açıklayıı bilgi vermeye çalışırken, hastalar 
da çekinmekten vazgeçerek daha açıklayıcı bilgi almak amacı ile doktorlarına soru sormaya başlamışlardır. Özellikle sağlık konusunda önleyiciliğin tedaviden daha öne çıkması ile sağlık hizmetlerinin boyutu da genişlemiştir (Okay, 2016 b, s.16-17). Sağlık iletişiminin bir disiplin olarak görülmesi zamanla artan önemi sayesinde olmuştur. Konu üzerine yapılan çalışmalar sayesinde insana dair davranışlar ve ilişkiler gelişmiştir. Çınarlı'nın (2008) ifade ettiği üzere sağlık iletişimi üzerine araştırmalar ivme kazanırken, kamu ve sağlıkla ilgili eğitimlerde de artış gözlemlenmiştir. Schwartzer ve Fuchs (1996)'ın yılındaki çalışmalarına göre özyeterlilik, sağlik davranışının doğru yürümesinde bir belirleyicidir. Sağlık açısından kişinin özyeterli sayılması için sağlı̆̆ına önem veriyor olması, yaşam tarzını değiştirmeden sağlığına kavuşamayacağını kabul etmiş olması, kendine inanarak tüm yapılması gereken adımları hekimi ya da diyetisyeni ile beraber çözeceğine inanması gereklidir. Bu yetkinliği kendinde görebilmesidir. Özyeterliliği güçlü olan insanlar doygun olarak devam ettikleri yaşamlarında başarıya, ulaşmak istedikleri hedefe daha odaklı olurken, engeller açısından daha mücadelecidirler. Diğer bir deyişle, davranış değişikliğine sahip oldukları öz güvenle içinde bulundukları durumu farklı bir boyuta taşıyabilmektedirler. Bandura (1977 a) yaptığı çalışmada insanların sonuca odaklı olduklarından bahsetmektedir. İnsanlar başarısina inanmadıkça bir iş üzerinde yeterli konsantre olamamaktadırlar. Trost ve arkadaşlarına (2002, s.1996-2001) göre öz yeterlilik gelişimi dört temel uygulama üzerine oturmaktadır:

1. Daha önce elde edilen deneyimler sonucunda elde edilen verimli performans (Mastery experience)

2. Benzer deneyimleri yaşayan kişilerin gözlemlenmesi (Vicarous Experiences)

3. Gerçekçi sınırlar içinde yapılan cesaretlendirmeler olarak görülen sosyal ikna ( Social persuasion)

4. Duygusal ve fizyolojik olarak verilen tepkiler (Sentimental Reaction)

Literatürde diyet programlarındaki uyum süreçleri incelendiğinde sadece değişime hazır olan bireyler üzerinde başarının daha etkin olduğu görülmektedir (Norris, Engelgau ve Narayan, 2001, s.561-587). Değişime hazır olmanın yanı sıra, ikna edici iletişim biçimi de kişinin doğru beslen- 
meye yönelik bilişsel yapısında ve hastalık durumunda da hastaların tutumlarında önemli değişikliklere yol açmaktadır. İnsanların pek çoğu karar alma aşamasında ikna edilmek istemektedirler (Özerkan ve İnceoğlu, 1997, s.59). İkna kelimesi Arapçadan gelmektedir. Kandırma, inandırma olarak Türkçeleşen bu kavramda kandırma tek yönlü bir aldatma olarak görülürken, inandırma ise karşılıklı rıza olarak tanımlanmaktadır. İngilizcesi "persuasion" olan bu kelime, ikna etmek olarak kullanılmaktadır. İletişim ile iç içe olan ikna kavramında "niyet" önemli bir unsurdur (Anık, 2006, s.36). Niyet kavramı merkezi bir rol üstlenerek ikna konusunda vazgeçilmezi oynamaktadır. Hasta olarak kendi sağlığını düşünen kişinin öncelikleri sağlığına kavuşmak olarak düşünüldüğünde bu kişinin kendi yetkinliğine inanması, sağlığının her şeyden önce geldiğini düşünerek niyetinin bu yönde olumlu ilerlemesi gerekmektedir. Hastanın hekimi veya diyetisyeni ile sağladığı iletişimde dürüstlük, düşüncelerin açıkça ifadesi ve ilişkide olumlu niyetle ilerleme önemlidir. Burada etkin olan husus, hastanın tutumları ve davranışları üzerinde değişiklik yapması gerektiğine olan inancıdır. Aristo (M.Ö. 384-322), Retorik adlı eserinde konuşan, söz ve dinleyenden bahsetmektedir. Teorisinde ethos, pathos ve logos olarak bahsettiği kavramlarda konuşmacının karakterinden, dinleyicinin takdirinden ve inanmasından bahsetmektedir. Doktorun meslek kimliği, hastanın takdiri ile düşüncede ikna edilmesi her ikisi arasındaki iletişimin önemini vurgulamaktadır. Bunun yanı sıra, konuşmacı olarak sağlık çalışanı hekimin dürüstlük, deneyim ve mizah gücü gibi özellikleri unvanı ile birleştiğinde hastanın ikna olmasını kolaylaştırmaktadır. Bu durum hastanın demografik yapısının iyi bilinmesi, hasta ile kurulan iletişim bağında hastanın düşüncelerine, tutum ve davranışlarına uygun diyet programı uygulanması, kısacası hekim ile hasta arasında bağ kurulması demektir.

Sosyolojik açıdan bireysel problemlerin toplumsal sorun olarak araşt1rılması ve açıklı̆ga kavuşturulması önem arz etmektedir. Bu nedenle katılımcıların görüşlerinin ortak ve farklı temalarını bulmak araştırmanın esas hedeflerinden biridir. Bu araştırma, kişinin sağlıklı beslenmeye yönelik düşüncelerinin analizini yapmaya odaklanırken, kendisinin eğitimi, yaşam koşulları, hayat biçimi perspektifinden incelenmesini amaçlamaktadır. İkna sürecinde hastaların eğitimi, yaşam koşulları, hayat biçimleri açı- 
sından öz yeterliliklerinin kendilerini tanıma ve hekimlerine inanma açısindan incelenmesi literatürde yok denecek kadar azdır. Bu nedenle, sağlıklı beslenme gayretinde olan insanların neredeyse tüm hayatlarını ömür boyu kontrol altına almaya çalıştıkları bir dönemde iknanın başarı ölçüsünün anlaşılması ve literatürdeki boşluğun kapatılmasına yönelik veriler elde edilmesine yönelik çalışmalar oldukça önemlidir. Bireyin alışkanlıklarından vazgeçmesi, sağllk kalitesi için doğru beslenmeye ikna edilmesi oldukça önemli ancak zor bir süreçtir. İnsanların sağlık kalitesi için de sağlıklı beslenmesi 2020 pandemi sürecinde oldukça önem kazanmıştır. Doğru yaklaşımın nasıl olması gerektiğinin anlaşılması ile kişinin doğru beslenmeye yönelik bilincinde artış söz konusu olacağı gibi hastalık durumunda da hasta ile doğru bir iletişim kurularak kendisinden istenilenleri uygulaması mümkün olacaktır. Bu şekilde, aile bütçesindeki sağlık harcamalarında azalma ve devlet bütçesinden sağlığa harcanan kalemde bir kaynak artışı olacağı ön görülmektedir. Yukarıda belirtilen bilgiler 1şığında bu araştırma, başlı başına bilgi sağlamayı ve literatüre katkı yapmayı hedeflemektedir.

\section{Problem Durumu}

Kadıköy / Fenerbahçe ve Maltepe / Yalı semtlerinde oturan kişilerin öz yeterlilik inançlarının seviyesi ve diyete ikna edilmedeki görüşleri ne durumdadir?

\section{Araştırmanın Alt Problemleri}

1. Katılımcıların perhiz ya da diyet öz yeterlilik inançları demografik yapılarına göre ne düzeydedir?

2. Katılımcıların diyet/perhiz öz yeterlilik inançları yaşlarına göre farkl1lık göstermekte midir?

3. Katılımcıların diyete / perhize ikna durumları ne düzeydedir?

4. Katılımcıların doktoru / diyetisyeni ile olan çabasında ikna boyutunu etkileyen nedir?

5. Katılımcların diyet / perhiz durumlarında ikna durumları aile yapısına göre değişmekte midir? 
6. Katılımcıların diyet/perhiz öz yeterlilik inançları ile ikna durumları eğitim seviyesine göre değişmekte midir?

\section{Yöntem}

Bu araştırmanın evreni İstanbul İli Maltepe İlçesi Yalı Mahallesi ve Kad1köy İlçesi Fenerbahçe Mahallesinde yaşayan toplam 100 bireyden oluşmaktadır. Veri toplama aracı olarak kullanılan ölçek sorularına verdikleri cevapların sonucunda diyet özyeterlik inancı ve diyete ikna süreci hakkında bilgi toplamayı hedeflemiştir. Araştırma, Marmara Üniversitesi Sağlık Bilimleri Enstitüsü Etik Kurulu'ndan izin alındıktan sonra 2020 yılı Eylül ve Aralık ayları arasında uygulanmıştır. Sağlıklı beslenme konusunda bireylerin bireysel, sosyal ve tıbbi açıdan ortaya çıkan davranışlarının ve düşüncelerinin tutumlarına yansıması üzerinde çalışılmıştır. Hastaların sosyo demografik yapıları ile öz yeterlilikleri karşılaştırılmasında özyeterlilik inancının ve iknanın öneminin ortaya çıkarılması söz konusudur.

$\mathrm{Bu}$ araştırmada kullanılan veri toplama araçları anket (survey) araştırmaları üzerinde Diyet Özetkinlik İnanç Ölçeği (DÖIÖ), İkna ölçeği ve araştırmacı tarafından hazırlanan Kişisel Bilgi Formudur.

\section{Araştırmanın Modeli}

Bu araştırmada üzerinde çalışılan evrenin davranışlarını ve düşüncelerini incelemeye yönelik betimsel çalışma içinde tarama modeli uygulanmıştır. Betimsel araştırma, araştırmacının uzun yıllar ikamet ettiği iki semt olan, aynı zamanda iki farklı demografik yapı içerisinde yer alan, bir semtte daha bireyselci düzende bir semtte ise daha geleneksel toplulukçu aile yapısı içinde yaşayan bireylerden oluşan İstanbul ili Maltepe ilçesi Yalı mahallesi ve Kadıköy ilçesi Fenerbahçe mahallesinde uygulanmıştır. Farklı meslek gruplarından olan 18 yaş üstü 24 erkek ve 76 kadın birey olmak üzere toplam 100 gönüllü katılımcıya olasılıksız örnekleme yönteminde kartopu yöntemi ile ulaşılmıştır. Araştırma bu bağlamda, katılımcıların belli bir konudaki fikirleri, duygu ve düşünceleri üzerinde inceleme yap- 
maktadır. Sosyo ekonomik düzeyleri değişkenlik gösteren bireyler gönüllü olarak araştırmaya katılım sağlamıştır. Katılım, pandemi sürecinde olunması nedeni ile soruları kağıt üzerinde cevaplamayı kabul etme şartı ile mümkün olmuştur. Her iki semtte ikamet eden birer kişi ile başlamış olan kartopu yöntemi, bu konuda kiminle anket çalışması yapılmasının fayda sağlayacağı sorularak başlatılmıştır. Her iki semt çok geniş bir alan içerisinde olduğu için evreni oluşturacak kişilere ulaşmanın zorluğu aşikardır. Bu nedenle her iki semtte de sağlıklı yaşam konusunda en fazla hassasiyete sahip olduğu düşünülen kişi ile görüşmeye başlanmıştır. $\mathrm{Bu}$ kişiye ulaşmak için "Bu konu hakkında en iyi bilen kimdir? Kiminle ilk görüşülse en doğru olur?" sorularına cevap aranmıştır. Araştırmacının deneyimleri, tecrübesi ve kuvvetli olan sosyal ilişkileri sayesinde her iki semtte de başkalarının güvenini kazanmış, sayılan, sevilen, sağlıklı beslenme konusunda hassas ve diyete özenli olan komşuyu bulmak diğer bir deyişle ilk kişiye ulaşmak için sorulan soruların cevaplarını bulmak zor olmamıştır. Görüşülen her katılımcının konu ile ilgili doğru bilgiyi sağlayabilecek başka kişileri tavsiye edip etmeyeceklerinin sorulması ve bu şekilde örneklem genişletilmesi sokak ortamında değil ev ortamında gerçekleşmiştir. Randevu ile ziyaret edilen gönüllü katılımcılara bilgilendirme yapılması sağlanmış, yazılı onam alınmıştır. Anketlerin teslim edilmesi sırasında yüz yüze görüşme ile konuya daha duyarlı oldukları ve daha samimi cevap verdikleri gözlemlenmiştir. Grix'in (2010) de bahsettiği gibi araştırmacının görüştüğü kişilerin güvenini kazanması önemlidir. İnsanlar güvenmedikleri takdirde bilgi vermekten imtina edebildikleri gibi yeni kişilere ulaşmak için referans da olmak istemeyebilmektedirler (Marshall, 1996, s.522-526). Soruların cevaplanmasında kendilerini rahat ortamda hissetmeleri için belli bir süre verilmiş, daha sonra anket cevapları elden yine kapıdan teslim alınmıştır. Bu sayede akıllarına takılan, sormak istedikleri sorular içinde firsat yaratılmıştır. Bu bağlamda doğal olarak ulaşılan her yeni kaynak araştırmada yeni bir ufuk açabilmiştir. Bu evreni oluşturan kitleye iki ayrı ölçekle yapılan ölçümler sonucu bireylerin hastalıklarına olan inançlarında diyetin onlar için öneminin sorgulanmasının yanı sıra sosyo demografik yapıları içerisinde kendi öz yeterlikleri de karşılaştırılmıştır. Bu karşılaştırmada hekimin / diyetisyenin katılımcıya hangi açıdan yaklaşımının kendisini hasta ya da danışan olarak sağlıklı beslenmeye daha fazla ikna ettiği incelenmiştir. Tüm bu çalışmalar araştırmacı 
tarafından geliştirilen genel bilgi formunda yer alan demografik veriler ışığında incelenmiştir. Bu forma ek olarak Diyet Öz etkinlik İnanç Ölçeği ve İkna Ölçeği soruları verilerek, elde edilen cevaplar üzerinden birebir gözlem yapılmıştır. Bulgular ve tartışma bölümü bu sonuca göre oluşmuştur.

\section{Verilerin Toplama Aracı}

Araştırma, üç bölüm içinde taranmıştır. Birinci bölümde bireylerin cinsiyet, yaş, eğitim durumu, medeni durumu, mesleği, aile yapısı, sağlık güvencesi, kronik rahatsızlığı, kilosu, boyu, aile gelir düzeyi üzerinde araştırmacı tarafından hazırlanmış olan demografik yapılarını belirten form kullanılmıştır. İkinci bölümde diyet yaparken öz yeterlilik inancının uyumu üzerinde yapılan ölçüm ve son olarak üçüncü bölümde diyetisyenin ya da hekimin hastaya uygulaması gereken diyet programında ne kadar ikna edebildiği incelenmiştir. Araştırma içindeki örneklemden doğru betimleme sağlanabilmesi araştırmanın olgusuna değer katmıştır. Araştırmada doğru örnekleme ulaşılması açısından kartopu yöntemi ile örneklem üzerinde üç ayrı safhada inceleme yapılmıştır:

Araştırmanın çalışma grubunu oluşturan katılımcıların eğitim durumları, yaşları, cinsiyetleri, oturdukları semtleri, sağlık güvenceleri, meslekleri ve medeni durumları ile ilgili bilgilere ilişkin araştırmacı tarafından geliştirilen sosyodemografik veri formuna göre demografik bilgiler aşağ1daki tablolarda yer almaktadır.

Çalışma grubunu oluşturan katılımcıların eğitim durumlarına göre dağllımı Tablo 1'de verilmiştir.

Tablo 1. Katılımcıların Eğitim Durumlarına Göre Dağılımı

\begin{tabular}{ll}
\hline Ĕ̆itim Düzeyi & $f$ \\
\hline İlkokul mezunu & - \\
Ortaokul mezunu & 8 \\
Lise mezunu & 14 \\
Üniversite mezunu & 64 \\
Lisansüstü & 14 \\
Toplam & 100 \\
\hline
\end{tabular}


Çalışma grubunu oluşturan katılımcıların çoğunluğunun üniversite mezunu (\%64'ünün) oldukları görülürken, ortaokul, lise ve lisansüstü eğitim almış katılımcıların sayısının az olduğu ve ilkokul mezunu hiçbir katılımcının olmadığı da görülmektedir.

Çalışma grubunu oluşturan katılımcıların yaşlarına göre dağılımı Tablo 2' de verilmiştir.

Tablo 2. Katılımcıların Yaşlarına Göre Dağılımı

\begin{tabular}{ll}
\hline Yaş & $N$ \\
\hline $18-28$ & 15 \\
$29-39$ & 23 \\
$40-50$ & 15 \\
$51-61$ & 24 \\
$62-72$ & 14 \\
73 ve üstü & 9 \\
\hline
\end{tabular}

Çalışma grubunu oluşturan katılımcıların yaşlarına göre dağılımı incelendiğinde yaşlara göre dağılımın dengeli olduğu görülmektedir.

Çalışma grubunu oluşturan katılımcıların cinsiyetine göre dağılımı Tablo 3'de verilmiştir.

Tablo 3. Katılımcıların Cinsiyetlerine Göre Dă̆ılımı

\begin{tabular}{ll}
\hline Cinsiyet & $N$ \\
\hline Kadın & 76 \\
Erkek & 24 \\
Toplam & 100 \\
\hline
\end{tabular}

Tablo 3 incelendiğinde çalışma grubunu oluşturan katılımcıların çoğunluğunun (\%76) kadın olduğu saptanmıştır.

Çalışma grubundaki katılımcıların ikamet ettikleri semtlere göre dağılımı Tablo 4'de sunulmuştur.

Tablo 4. Katılımcıların Oturdukları Semtlere Göre Dağılımı

\begin{tabular}{ll}
\hline Semt & $N$ \\
\hline Kadıköy/Fenerbahçe & 50 \\
Maltepe/Yalı & 50 \\
Toplam & 100 \\
\hline
\end{tabular}


Tablo 4 incelendiğinde çalışma grubunu oluşturan katılımcıların yarısının Kadıköy/Fenerbahçe' de diğer yarısının ise Maltepe/Yalı'da oturdukları görülmektedir.

Çalışma grubunu oluşturan katılımcıların sağlık güvencelerine göre dağılımı Tablo 5'de verilmiştir.

Tablo 5. Katılımcıların Sağlık Güvencelerine Göre Dă̆ılımı

\begin{tabular}{ll}
\hline Sağllk Güvencesi & $N$ \\
\hline SSSK, Bağkur, Emekli Sandığı & 57 \\
Özel Sağlık Sigortası & 43 \\
Toplam & 100 \\
\hline
\end{tabular}

Tablo 5 incelendiğinde çalışma grubunu oluşturan katılımcıların yarısından bir miktar fazlasının (\%57'sinin) sağlık güvencesinin SSK, Bağkur ve Emekli sandığı olduğu görülürken, yarısına yakınının ise özel sağlık sigortası olduğu görülmektedir.

Çalışma grubunu oluşturan katılımcıların mesleklerine göre dağılımı Tablo 6'de verilmiştir.

Tablo 6. Katılımcıların Mesleklerine Göre Dağılımı

\begin{tabular}{ll}
\hline Meslek & $N$ \\
\hline Öğrenci & - \\
Ev hanımı & 17 \\
İşçi & - \\
Memur & 12 \\
Özel sektör & 30 \\
Serbest meslek & 17 \\
Emekli & 24 \\
Toplam & - \\
\hline
\end{tabular}

Tablo 6 incelendiğinde çalışma grubunu oluşturan katılımcılardan özel sektörde çalışan ve emekli olanlarının sayısının diğerlerinden fazla olduğu görülürken (\%30 ve \%24) öğrenci ve işçi olan hiçbir katılımcının olmadığ 1 da görülmektedir.

Çalışma grubunu oluşturan katılımcıların medeni durumlarına göre dağılımı Tablo 7'de verilmiştir. 
Tablo 7. Katılımcıların Medeni Durumlarına Göre Dağılımı

\begin{tabular}{ll}
\hline Medeni Durum & $N$ \\
\hline Bekar & 20 \\
Evli & 72 \\
\hline
\end{tabular}

Tablo 7 incelendiğinde çalışma grubunu oluşturan katılımcıların çoğunluğunun evli olduğu görülürken, az bir kısmının ise bekâr olduğu görülmektedir.

Araştırmada kullanılan ölçeklerden biri Diyet Öz Yeterlilik İnançları Ölçeğidir. (DÖiÖ). Bahsi geçen ölçek, Bandura'nın (1977 a) özetkinlik kavramından yola çıkılarak Özlem Sertel Berk ve Duygu Yüksel (2014) tarafından hazırlanmıştır. Üç farklı Türk Dili ve Edebiyatı uzmanı tarafından dil kuralları açısından incelenmiş ve son haline getirilmiştir. Bu ölçek bireyin tedaviye hazır oluş durumunu ölçmek amacı ile hazırlanmıştır. Ölçek, 37 maddeden oluşan "Genel İnançlar", "Tıbbi Boyut", ve "Hazırlık/ Kontrol" olarak adlandırılan üç faktörden oluşan bir ölçüm aracıdır. Diğer bir deyişle, bağımlı değişkenler, diyet öncesi genel inançlar, tıbbi inançlar ve hazırlık inançları alt boyutlarından oluşan üç faktör halindeki öz yeterlilik inançlarından oluşmaktadır. Faktörlerin iç tutarlılık katsayıları, "Genel İnançlar" için Cronbach Alfa .95, "Tıbbi İnançlar" için .86 ve "Kontrol ve Hazırlık İnançları" için ise .75 olarak hesaplanmıştır. Anket, Likert Ölçeğine uygun olarak 1, "hiç uygun değil" 2, "uygun değil" 3, "az uygun" 4, "uygun" 5, "çok uygun" anlamını taşıyan 5'li ifade şeklinde hazırlanmıştır. Sırası ile 1 . Seçenek 1 puan, 2 . Seçenek 2 puan, 3. Seçenek 3 puan, 4. Seçenek 4 puan ve 5 . Seçenek 5 puan olarak hesaplanmıştır. Ölçeğin kullanımı için ölçeğin yetkilileri olan Doç. Dr. Özlem Sertel Berk ve Uzman Psikolog Duygu Yüksel'den yazılı izin alınmıştır. Bir doktor ya da diyetisyenin güvenilir insan özelliklerini bulmak amacı ile araştırmada "ikna edebilme özellikleri" ni de ortaya çıkarmak hedeflenmiştir. Bu aşamada araştırmacı tarafından Patton'un da (2014, s.350) üzerinde durduğu gibi katılımcıların konu hakkındaki duygu ve düşüncelerini anlayabilmek ve tahlil edebilmek için düşünce ve değer soruları ile duygu ve his sorularına yer veren araştırma da yapılması gerektiği üzerinde durulmuştur. Araştırma sonuçlarının betimlenmesinde yer alan diğer ölçek olan ikna Ölçeği, Prof. Dr. S. Ece Karadoğan (2003) tarafından hazırlanmıştır. Ölçek, 
güvenilir olmak, yalan söylememek, tutarlı olmak, beden dili, bilgili olmak ve kim olduğu üzerine 6 faktörden ve 44 ifadeden oluşmaktadır. Ölçek, ALPHA güvenlik testinde o, 9086 çıkmıştır. 0,70 ve üstü çok güvenilir olarak yorumlanmaktadır. Bu durumda ölçeğin güvenirliliği çok yüksek olduğu görülmektedir. Ölçek, anket formunda likert Ölçeğine uygun olarak "çok gerekli", "gerekli", "fark etmez", "gerekli değil” ve "hiç gerekli değil" şeklinde 5'li ölçek kullanılarak hazırlanmıştır. Deneklerden alınan sonuçlar çok gerekli $=5$ puan, gerekli $=4$ puan, fark etmez $=3$ puan, gerekli değil= 2 puan ve hiç gerekli değil=1 puan olarak hesaplanmıştır. Ölçeğin kullanımı için Prof. Dr. S. Ece Karadoğan'dan yazılı izin alınmıştır.

\section{Varsayım}

$\mathrm{Bu}$ araştırmanın temel varsayımı, kişilerin diyet özyeterlik inancı ile diyete ikna süreçlerindeki düşüncelerini ölçmek için geliştirilen anketin güvenilir ve geçerli bir ölçüm aracı olmasıdır. Araştırmanın diğer varsayımı, demografik yapının kişiler üzerinde etkisinin büyük olduğudur.

\section{Kisitlamalar}

Araştırma 2020 yılı Eylül ve Aralık ayları arasında İstanbul İl Merkezi Maltepe ve Kadıköy ilçelerinde yaşayan 18 yaş üstü 76 kadın ve 24 erkeğe olmak üzere toplam 100 bireyden uygulanmiş olup, kendilerinden elde edilen cevaplar ile sınırlıdır. Araştırma sonuçları toplam 100 mahalle sakinine uygulanan anket formunun ölçtüğü nitelikle sınırlıdır. İstanbul ili Maltepe / Yalı ve Kadıköy / Fenerbahçe ilçesi dışında bir genelleme söz konusu değildir.

\section{Bulgular}

Bu bölümde, araştırma bulgularına ve bu bulgularla ilgili değerlendirmelere yer verilmiştir. Öncelikle araştırmada kullanılan ölçeklerin güvenilirliği belirlemek amacıyla Cronbach Alfa güvenirlik katsayısı kullanılmıştır. 
Analiz sonucunda 36 maddeden oluşan diyet öz yeterlik inançları ölçeğinin Cronbach Alfa güvenirlik katsayısı $(\alpha)$ 0.95, 44 maddeden oluşan ikna ölçeğinin güvenirlik katsayısı ise $(\alpha) 0.72$ olarak bulunmuştur.

Diyet Öz Yeterlik İnançları Ölçeği ile İkna Ölçeğinin güvenirlik analizi sonuçları Tablo 8’de verilmiştir.

Tablo 8. Aile Hayatı ve Çocuk Yetiştirme Tutumu Ölçeği Alt Boyutlara Ait Güvenirlik Analizi Sonuçları

\begin{tabular}{ll}
\hline Araştırmada Kullanılan Ölçekler & Cronbach Alfa Değerleri \\
\hline Diyet Öz Yeterlik İnançları Ölçeği & 0.95 \\
İkna Ölçeği & 0.72 \\
\hline
\end{tabular}

Araştırmada yer alan katılımcıların “Diyet Öz Yeterlik İnançları Ölçeği" ile "İkna Ölçeği” ne verdikleri cevaplara dayalı olarak elde edilen veriler parametrik test varsayımları ile bakılmıştır. Elde edilen veriler normal dağılımda ve varyansların homojenliğinde istatistiki açıdan teste tabi tutulmuştur. Gruplardan elde edilen verilerin normal dağılım gösterip göstermediği betimsel yöntemler, grafiksel yöntemler ve hipotez testiyle incelenmiştir. Yukarıda bahsedilen yöntemler kullanılarak hipotez testi için kullanılan Kolmogorov-Smirnov testi sonucunda p değerleri 0,05'den küçük, çarpıklık-basıklık katsayıları ve indeksleri istenilen aralıkta olmadığ1 ve grafikler de normalliğe ilişkin gösterimler sunmadığı için verilerin dağılımının normal olmadığı söylenebilir. Varyansların homojenliği ise "Levene's Test of Equality of Error Variances (Levene Hata Varyanslar1 Eşitliği Testi)" ile incelenmiş ve varyanların homojen olmadığ görülmüştür. Dolayısıyla her iki ölçek için de homojenliğin sağlanmadığı görülmüştür. Bu bağlamda, dağılımın normallik varsayımının yerine getirilmediği sonucuna ulaşılmıştır. Verilerin analizinde parametrik olmayan istatistiksel analizler kullanılmıştır.

\section{Verilerin Analizi}

Verilerin analizinde ilk olarak katılımcıların "Diyet Öz yeterlik İnançları Ölçeği" ve "İkna Ölçeği" nden aldıkları puanların ne düzeyde olduğu belirlemek amacıyla sözü edilen ölçekten elde edilen puanlara dayalı olarak 
aritmetik ortalama, standart sapma, en yüksek ve en düşük değerler hesaplanmıştır. İkinci olarak araştırmada yer alan katılımcıların “Diyet Öz yeterlik İnançları Ölçeği” ve "İkna Ölçeği"nden aldıkları puanların eğitim durumu, yaş, meslek değişkenlerine göre anlamlı farklılık gösterip göstermediğine "Kruskal-Wallis H-testi" ile, söz konusu puanların katılımcların cinsiyetine, sağlık güvencesine, yaşadıkları semte ve medeni duruma bağlı olarak anlamlı farklılık gösterip göstermediğine ise "Mann Whitney U-testi" ile bakılmıştır. Son olarak araştırmada değişkenler arasındaki ilişkinin gücünü kararlaştırmada etki büyüklükleri (r) hesaplanmış ve 0.10, 0.30 ve 0.50 düzeyindeki değerler aynı sırayla küçük, orta ve büyük etki büyüklüğü olarak yorumlanmıştır (Cohen, 1988, 1992). Araştırmada eğitim durumu, yaş, meslek değişkenlerinde grup sayılarının fazla olması hatanın artmasına sebep olmaktadır. Bu nedenle bu değişkenlerin karşılaştırılmasında I. Tip hatayı kontrol etmek amacıyla Bonferroni düzeltmesi (correction) yapılmıştır. Bonferroni düzeltmesi anlamlılık düzeyi / grup sayısı formülü ile belirlenmektedir (Vialatte ve Cichocki, 2008). Bu araştırmada grup sayısı dört olduğunda anlamlılık düzeyi Bonferroni düzeltmesi ile 0.012 , beş olduğunda ise 0.01 olarak belirlenmiştir. Dolayısıyla Kruskal-Wallis $\mathrm{H}$ analizi sonrası ortaya çıkan kategoriler arasındaki farkın test edilmesi için kullanılan Mann Whitney $U$ testi için anlamlılık düzeyi dört grup için $p=0,012$ ve beş grup için $p=0,01$ olarak alınmıştır. Grup sayısının iki olduğu durumlarda yapılan karşılaştırmalarda ise Bonferroni düzeltmesi kullanılmamış, anlamlılık düzeyi 0.05 olarak alınmıştır. Verilerin analizi SPSS 23.0 paket programında yapılmıştır.

\section{Katılımcıların “Diyet Öz yeterlik İnançları Ölçeği” ve “İkna Öl- çeği"nden Elde Ettikleri Puanlara İlişsin Betimsel Analizler}

Araştırmada yer alan katılımcıların "Diyet Öz yeterlik İnançları Ölçeği" ve "İkna Ölçeği"nden aldıkları puanlara ilişkin betimsel analizler Tablo 9 ' da verilmiştir.

Tablo 9 incelendiğinde diyet öz yeterlik inançları ölçeği ile ikna ölçeğinden alınabilecek en yüksek puanlar sırasıyla 171 ve 198 iken, katılımcıların sözü edilen ölçekten aldıkları puanların ortalamasının 135.25 ve 182.09 olduğu görülmektedir. 
Tablo 9. Diyet Öz yeterlik İnançları Ölçeği ve "İkna Ölçek"lerine İlişkin Betimsel Analiz Dĕgerleri

\begin{tabular}{llllll}
\hline $\begin{array}{l}\text { Araştırmada Kullanılan Öl- } \\
\text { çekler }\end{array}$ & $\mathrm{N}$ & $\begin{array}{l}\text { En dü- } \\
\text { şük }\end{array}$ & En yüksek & $\bar{X}$ & Ss \\
\hline $\begin{array}{l}\text { Diyet Öz yeterlik İnançları } \\
\text { Ölçeği }\end{array}$ & 100 & 75 & 171 & 135.25 & 26.83 \\
İkna Ölçeği & 100 & 161 & 198 & 182.09 & 9.62 \\
\hline
\end{tabular}

Bu bulgular incelendiğinde, katılımcıların hem diyet öz yeterlik inançları ölçeği hem de ikna ölçeğinden aldıkları puanların yüksek düzeyde olduğu yani katılımcıların öz yeterlik inançlarının ve diyete ikna edilme durumlarının yüksek düzeyde olduğu görülmektedir.

Diyet Öz yeterlik İnançlan Ölçeği ve İkna Ölçeğiyle Çeşitli Değişkenler Arasındaki Analizlere İlişkin Bulgular: Bu bölümde katılımcıların eğitim düzeyine, yaşlarına, cinsiyetlerine, sağlık güvencelerine, yaşadıkları semte, mesleklerine ve medeni durumlarına göre oluşan değişkenler üzerindeki analiz sonuçları verilmektedir.

Diyet Öz yeterlik İnançları Ölçeği ve İkna Ölçeğinden elde edilen Puanların Ĕ̆itim Düzeyine Göre Analiz Sonuçlarn: Araştırmada yer alan katılımcıların diyet öz yeterlik inançları ölçeği ve ikna ölçeğinden elde ettikleri puan ortalamalarının katılımcıların eğitim durumlarına göre farklılık gösterip göstermediğine Kruskal-Wallis H-Testi ile bakılmış ve sonuçlar Tablo 10'da verilmiştir.

Tablo 10. Diyet Öz yeterlik İnançlarn Ölçeği ve İkna Ölçeği Puanlarnnn Eğitim Durumuna Göre Kruskal-Wallis H Testi Sonuçlarn

\begin{tabular}{|c|c|c|c|c|c|c|c|c|}
\hline $\begin{array}{l}\text { Araştır- } \\
\text { mada Kul- } \\
\text { lanılan Öl- } \\
\text { çekler }\end{array}$ & Ĕgitim Durumu & $n$ & $\begin{array}{l}\text { Sira } \\
\text { orta.1 }\end{array}$ & $S d$ & $\chi^{2}$ & $p$ & $\begin{array}{l}\text { An- } \\
\text { lamln } \\
\text { fark }\end{array}$ & $r$ \\
\hline Diyet Öz & İlkokul mezunu & - & - & 3 & 32.75 & $0.00^{*}$ & $2-4,3-$ & 0.54 , \\
\hline \multirow{4}{*}{$\begin{array}{l}\text { Yeterlik Ol- } \\
\text { çeği }\end{array}$} & Ortaokul mezunu & 8 & 89.00 & & & & $4,4-5$ & 0.34 , \\
\hline & Lise mezunu & 14 & 64.50 & & & & & 0.38 \\
\hline & Üniversite mezunu & 64 & 38.85 & & & & & \\
\hline & Lisansüstü & 14 & 61.50 & & & & & \\
\hline \multirow{5}{*}{ İkna Ölçeği } & İlkokul mezunu & - & - & 3 & 17.17 & $0.00^{*}$ & $4-5$ & \\
\hline & Ortaokul mezunu & 8 & 53.57 & & & & & 0.41 \\
\hline & Lise mezunu & 14 & 56.45 & & & & & \\
\hline & Üniversite mezunu & 64 & 42.77 & & & & & \\
\hline & Lisansüstü & 14 & 76.50 & & & & & \\
\hline
\end{tabular}


Tablo 10 incelendiğinde, sırasıyla Diyet Öz yeterlik İnancı Ölçeği ve İkna Ölçeğinden elde edilen puan ortalamalarının eğitim durumuna göre anlamlı farklılık gösterdiği görülmektedir $\quad\left(\chi^{2}(3)=32.75,\left(\chi^{2}(3)=17.17\right.\right.$; $\mathrm{p}<0.05)$. Çıkan farkın hangi grubun lehine olduğunu bulmak için MannWhitney U testi yapılmıştır. Mann-Whitney U testi sonucunda Diyet Öz yeterlik ölçeğinde ortaokul ve lise mezunu katılımcıların puanlarının üniversite mezunlarından, yüksek lisans/doktora mezunlarının üniversite mezunlarından yüksek olduğu görülürken, ikna ölçeğinde ise yüksek lisans/doktora mezunu katılımcların puanlarının üniversite mezunlarından daha yüksek olduğu ve farkların anlamlı olduğu bulunmuştur. Yapılan analizler sonucunda etki büyüklükleri her bir ikili grup için ayrı ayrı hesaplanmış ve etki katsayısının genel anlamda yüksek ve yükseğe yakın olduğu yani gruplar arası farkın büyük olduğu görülmüştür. Sonuç olarak eğitim durumu değişkeninin diyet öz yeterlik inançları ve kişilerin diyete ikna edilme durumları için önemli bir değişken olduğu söylenebilir.

Diyet Öz yeterlik Inançları Ölçeği ve İkna Ölçeğinden elde edilen Puanlarnn Yaşa Göre Analiz Sonuçları: Araştırmada yer alan katılımcıların diyet öz yeterlik inançları ölçeği ve ikna ölçeğinden elde ettikleri puan ortalamalarının katılımcıların yaşına göre farklılık gösterip göstermediğine Kruskal-Wallis H-Testi ile bakılmış ve sonuçlar Tablo 11'de verilmiştir.

Tablo 11. Diyet Öz yeterlik Ínançları Ölçeği ve İkna Ölçeği Puanlarının Yaşa Göre Kruskal-Wallis H Testi Sonuçları

\begin{tabular}{lllllllll}
\hline $\begin{array}{l}\text { Araştırmada Kul- } \\
\text { lanılan Ölçekler }\end{array}$ & Yaş & $n$ & $\begin{array}{l}\text { Sira ortala- } \\
\text { ması }\end{array}$ & $S d$ & $\chi^{2}$ & $p$ & $\begin{array}{l}\text { Anlamlı } \\
\text { fark }\end{array}$ & $r$ \\
\hline Diyet Öz Yeterlik & $18-28$ & 15 & 29.67 & 5 & 19.86 & 0.00 & $1-2,1-4$ & $0.52,0.64$ \\
Ölçeği & $29-39$ & 23 & 63.04 & & & & & \\
& $40-50$ & 15 & 39.20 & & & & & \\
& $51-61$ & 24 & 62.90 & & & & & \\
İkna Ölçeği & $62-72$ & 14 & 42.46 & & & & \\
& 72 ve üzeri & 9 & 51.44 & 5 & 15.73 & & \\
& $18-28$ & 15 & 43.20 & & & $* .01$ & & \\
& $29-39$ & 23 & 64.83 & & & & & \\
& $40-50$ & 15 & 39.73 & & & & & \\
& $51-61$ & 24 & 51.83 & & & & & \\
& $62-72$ & 14 & 59.00 & & & & & \\
& 72 ve üzeri & 9 & 27.22 & & & & \\
\hline
\end{tabular}

${ }^{*} p<0.05$ 
Tablo 11 incelendiğinde, sırasıyla Diyet Öz yeterlik İnancı Ölçeği ve İkna Ölçeğinden elde edilen puan ortalamalarının yaşa göre anlamlı farklilık gösterdiği görülmektedir ( $\chi^{2}(5)=19.86,\left(\chi^{2}(2)=15.73\right.$; p<0.05). Çıkan farkın hangi grubun lehine olduğunu bulmak için Mann-Whitney U testi yapılmıştır. Mann-Whitney U testi sonucunda Diyet Öz yeterlik ölçeğinde 29-39 ile 51-61 yaş aralığındaki katılımcıların puanlarının 18-28 yaş aralığındaki katılımcıların puanlarından daha yüksek olduğu görülürken, ikna ölçeğinde ise 29-39 yaş aralığındaki katılımcıların puanlarının 40-50 yaş aralığındaki katılımcıların puanlarından daha yüksek olduğu ve farkın anlamlı olduğu bulunmuştur. Yapılan analizler sonucunda etki büyüklükleri her bir ikili grup için ayrı ayrı hesaplanmış ve etki katsayısının genel anlamda yüksek olduğu yani gruplar arası farkın büyük olduğu görülmüştür. Sonuç olarak yaş değişkeninin diyet öz yeterlik inançları ve kişilerin diyete ikna edilme durumları için önemli bir değişken olduğu söylenebilir.

Diyet Öz yeterlik İnançları Ölçeği ve İkna Ölçeğinden elde edilen Puanların Cinsiyete Göre Analiz Sonuçları: Araştırmada yer alan katılımcların diyet öz yeterlik inançları ölçeği ve ikna ölçeğinden elde ettikleri puan ortalamalarının katılımcıların cinsiyetine göre farklılık gösterip göstermediğine Mann-Whitney U Testi ile bakılmış ve sonuçlar Tablo 12' de verilmiştir.

Tablo 12. Diyet Öz yeterlik İnançları Ölçeği ve İkna Ölçeği Puanlarının Katılımcılaron Cinsiyetine Göre Mann-Whitney U Testi Sonuçları

\begin{tabular}{|c|c|c|c|c|c|c|}
\hline $\begin{array}{l}\text { Araştırmada } \\
\text { kullanılan ölçek- } \\
\text { ler }\end{array}$ & Cinsiyet & $n$ & $\begin{array}{l}\text { Sira ortala- } \\
\text { masi }\end{array}$ & Sira toplamı & $u$ & $p$ \\
\hline Diyet Öz Yeterlik & Kadın & 76 & 52.70 & 4005.50 & 744.50 & 0.18 \\
\hline \multirow{2}{*}{ Ölçeği } & Erkek & 24 & 43.52 & 1044.50 & & \\
\hline & Kadın & 76 & 50.79 & 3860.00 & 890.00 & 0.86 \\
\hline İkna Ölçeği & Erkek & 24 & 49.58 & 1190.00 & & \\
\hline
\end{tabular}

Tablo 12 incelendiğinde katılımcıların diyet öz yeterlik inançları ölçeği ile ikna ölçeğinden elde ettikleri puan ortalamalarının cinsiyete göre anlamlı farklılık göstermediği görülmektedir ( $U=744.50, U=890.00$; $p>0.05)$. 
$\mathrm{Bu}$ açıdan ele alındığında katılımcıların cinsiyetinin diyet öz yeterlik inançlarını ve diyete ikna durumlarını etkileyen önemli bir değişken olmadığı söylenebilir.

\section{Diyet Öz yeterlik İnançları Ölçeği ve İkna Ölçeğinden elde edilen Pu- anların Sağlık Güvencesine Göre Analiz Sonuçları}

Araştırmada yer alan katılımcıların diyet öz yeterlik inançları ölçeği ve ikna ölçeğinden elde ettikleri puan ortalamalarının katılımcıların sağlık güvencesine göre farklılık gösterip göstermediğine Mann-Whitney U Testi ile bakılmış ve sonuçlar Tablo 13'de verilmiştir.

Tablo 13. Diyet Öz yeterlik İnançları Ölçeği ve İkna Ölçeği Puanlarının Katılımcıların Sağllk Güvencesine Göre Mann-Whitney U Testi Sonuçları

\begin{tabular}{|c|c|c|c|c|c|c|}
\hline $\begin{array}{l}\text { Araştırmada } \\
\text { kullanılan ölçek- } \\
\text { ler }\end{array}$ & $\begin{array}{l}\text { Sağlık Gü- } \\
\text { vencesi }\end{array}$ & $n$ & $\begin{array}{l}\text { Sira ortala- } \\
\text { masi }\end{array}$ & Stra toplam & $u$ & $p$ \\
\hline \multirow[t]{2}{*}{$\begin{array}{l}\text { Diyet Öz Yeterlik } \\
\text { Ölçeği }\end{array}$} & $\begin{array}{l}\text { SSK, Bağ- } \\
\text { kur, } \\
\text { Emekli }\end{array}$ & 57 & 46.49 & 2650.00 & 997.00 & 0.11 \\
\hline & Sandığ1 & 43 & 55.81 & 2400.00 & & \\
\hline \multirow[t]{2}{*}{ İkna Ölçeği } & $\begin{array}{l}\text { Özel si- } \\
\text { gorta } \\
\text { SSK, Bağ- }\end{array}$ & 57 & 52.02 & 2965.00 & 1139.00 & 0.55 \\
\hline & $\begin{array}{l}\text { kur, } \\
\text { Emekli } \\
\text { Sandığ1 } \\
\text { Özel si- } \\
\text { gorta }\end{array}$ & 43 & 48.49 & 2085.00 & & \\
\hline
\end{tabular}

Tablo 13 incelendiğinde katılımcıların diyet öz yeterlik inançları ölçeği ile ikna ölçeğinden elde ettikleri puan ortalamalarının sağlık güvencesine göre anlamlı farklılık göstermediği görülmektedir (U=997.00, U=1139.00; $\mathrm{p}>0.05)$. Bu açıdan ele alındığında katılımcıların sağlık güvencesinin diyet öz yeterlik inançlarını ve diyete ikna durumlarını etkileyen önemli bir değişken olmadığı söylenebilir. 
Diyet Öz yeterlik İnançları Ölçeği ve İkna Ölçeğinden elde edilen Puanlarnn Yaşadıkları Semte Göre Analiz Sonuçlarn: Araştırmada yer alan katılımcıların diyet öz yeterlik inançları ölçeği ve ikna ölçeğinden elde ettikleri puan ortalamalarının katılımcıların yaşadıkları semte göre farklılık gösterip göstermediğine Mann-Whitney U Testi ile bakılmış ve sonuçlar Tablo 14'de verilmiştir.

Tablo 14. Diyet Öz yeterlik İnançları Ölçeği ve İkna Ölçeği Puanlarının Katılımcıların Yaşadikları Semte Göre Mann-Whitney U Testi Sonuçları

\begin{tabular}{|c|c|c|c|c|c|c|c|}
\hline $\begin{array}{l}\text { Araştırmada } \\
\text { kullanılan öl- } \\
\text { çekler }\end{array}$ & Yaşanan Semt & $n$ & Sira ort. & $\begin{array}{l}\text { Sira } \\
\text { top. }\end{array}$ & $U$ & $p$ & $r$ \\
\hline \multirow{4}{*}{$\begin{array}{l}\text { Diyet Öz Ye- } \\
\text { terlik Ölçeği } \\
\text { İkna Ölçeği }\end{array}$} & Kadıköy/Fenerbahçe & 50 & 41.38 & 2069.00 & \multirow[t]{2}{*}{794.00} & \multirow[t]{2}{*}{$0.00^{*}$} & \multirow[t]{2}{*}{0.31} \\
\hline & Maltepe/Yalı & 50 & 59.62 & 2981.00 & & & \\
\hline & Kadiköy/Fenerbahçe & 50 & 37.10 & 580.00 & \multirow[t]{2}{*}{580.00} & \multirow[t]{2}{*}{$0.00^{*}$} & \multirow[t]{2}{*}{0.46} \\
\hline & Maltepe/Yalı & 50 & 63.90 & 1855.00 & & & \\
\hline
\end{tabular}

${ }^{*} p<0.05$

Tablo 14 incelendiğinde katılımcıların diyet öz yeterlik inançları ölçeği ile ikna ölçeğinden elde ettikleri puan ortalamalarının yaşanan semte göre anlamlı farklılık gösterdiği görülmektedir ( $U=794.00, U=580.00 ; p<0.05)$. Sıra ortalamaları incelendiğinde hem diyet öz yeterlik inancı ölçeği hem de ikna ölçeğinde Maltepe/Yalı'da oturanların sıra ortalamalarının Kadıköy/Fenerbahçe' de oturanlardan daha yüksek olduğu görülmektedir. Bununla birlikte etki büyüklükleri incelendiğinde ise 0.31 ve 0.46 olarak bulunmuştur. Buna göre diyet öz yeterlik ölçeğinde etki orta düzeyde ikna ölçeğinde ise yüksek düzeydedir. Kadıköy/Fenerbahçe' de oturan katılımcllar ile Maltepe/Yalı'da oturan katılımcıların diyet öz yeterlik puanları arasındaki farkın orta düzeyde, diyete ikna durumları arasındaki farkın ise yüksek düzeyde olduğu görülmektedir. Bu açıdan ele alındığında katılımcıların oturdukları semtin diyet öz yeterlik inançları ile diyete ikna durumlarını etkileyen önemli bir değişken olduğu söylenebilir.

Diyet Öz yeterlik İnançları Ölçeği ve İkna Ölçeğinden elde edilen Puanlarnn Mesleğe Göre Analiz Sonuçları: Araştırmada yer alan katılımcıların diyet öz yeterlik inançları ölçeği ve ikna ölçeğinden elde ettikleri puan ortalamalarının katılımcların mesleğine göre farklılık gösterip göstermediğine Kruskal-Wallis H-Testi ile bakılmış ve sonuçlar Tablo 15' de verilmiştir. 
Tablo 15. Diyet Öz yeterlik İnançlan Ölçeği ve İkna Ölçeği Puanlarının Mesleğe Göre Kruskal-Wallis H Testi Sonuçlarn

\begin{tabular}{|c|c|c|c|c|c|c|c|c|}
\hline $\begin{array}{l}\text { Araştırmada } \\
\text { Kullanılan } \\
\text { Ölçekler } \\
\end{array}$ & Meslek & $n$ & $\begin{array}{l}\text { Sira orta- } \\
\text { lamast }\end{array}$ & $\begin{array}{l}S \\
d\end{array}$ & $\chi^{2}$ & $p$ & $\begin{array}{l}\text { An- } \\
\text { laml } \\
\text { fark }\end{array}$ & $r$ \\
\hline \multirow{7}{*}{$\begin{array}{l}\text { Diyet Öz Ye- } \\
\text { terlik Ölçeği }\end{array}$} & Öğrenci & - & - & 4 & 36.43 & $0.00^{*}$ & $2-4,2-5$ & 0.68 \\
\hline & Ev hanımı & 17 & 87.94 & & & & $2-6,2-7$ & 0.66 \\
\hline & İşçi & - & - & & & & & 0.86 \\
\hline & Memur & 12 & 46.50 & & & & & 0.85 \\
\hline & Özel Sektör & 30 & 46.17 & & & & & \\
\hline & Serbest Meslek & 17 & 33.97 & & & & & \\
\hline & Emekli & 24 & 43.19 & & & & & \\
\hline \multirow[t]{7}{*}{ İkna Ölçeği } & Öğrenci & - & - & 4 & 15.27 & $0.00^{*}$ & $2-7,4-7$ & \\
\hline & Ev hanımı & 17 & 65.12 & & & & & \\
\hline & İşçi & - & - & & & & & 0.65 \\
\hline & Memur & 12 & 64.50 & & & & & 0.52 \\
\hline & Özel Sektör & 30 & 55.28 & & & & & \\
\hline & Serbest Meslek & 17 & 43.94 & & & & & \\
\hline & Emekli & 24 & 34.12 & & & & & \\
\hline
\end{tabular}

${ }^{*} p<0.05$

Tablo 15 incelendiğinde, sırasıyla Diyet Öz yeterlik İnancı Ölçeği ve İkna Ölçeğinden elde edilen puan ortalamalarının mesleğe göre anlamlı farklılık gösterdiği görülmektedir $\left(\chi^{2}(4)=36.43,\left(\chi^{2}(2)=15.27 ; \mathrm{p}<0.05\right)\right.$. Çıkan farkın hangi grubun lehine olduğunu bulmak için Mann-Whitney U testi yapılmıştır. Mann-Whitney U testi sonucunda Diyet Öz yeterlik ölçeğinde ev hanımı olan katılımcıların puanlarının memur, özel sektörde çalışan, serbest meslek ve emekli olan katılımcıların puanlarından daha yüksek olduğu görülürken, ikna ölçeğinde ise ev hanımı ve memur olan katılımcıların puanlarının emekli katılımcıların puanlarından daha yüksek olduğu ve farkın anlamlı olduğu bulunmuştur. Yapılan analizler sonucunda etki büyüklükleri her bir ikili grup için ayrı ayrı hesaplanmış ve etki katsayısının genel anlamda yüksek olduğu yani gruplar arası farkın büyük olduğu görülmüştür. Sonuç olarak meslek değişkeninin diyet öz yeterlik inançları ve kişilerin diyete ikna edilme durumları için önemli bir değişken olduğu söylenebilir.

Diyet Öz yeterlik Inançlar Ölçeği ve İkna Ölçeğinden elde edilen Puanlarn Medeni Duruma Göre Analiz Sonuçlarn: Araştırmada yer alan katı- 
lımcıların diyet öz yeterlik inançları ölçeği ve ikna ölçeğinden elde ettikleri puan ortalamalarının katılımcıların medeni durumuna göre farklılık gösterip göstermediğine Mann-Whitney U Testi ile bakılmış ve sonuçlar Tablo 16' da verilmiştir.

Tablo 16. Diyet Öz yeterlik İnançları Ölçeği ve İkna Ölçeği Puanlarının Medeni Duruma Göre Mann-Whitney U Testi Sonuçları

\begin{tabular}{llllllll}
\hline $\begin{array}{l}\text { Araştırmada } \\
\text { kullanılan öl- } \\
\text { çekler }\end{array}$ & $\begin{array}{l}\text { Medeni } \\
\text { Durum }\end{array}$ & $\boldsymbol{n}$ & $\begin{array}{l}\text { Stra ortala- } \\
\text { ması }\end{array}$ & $\begin{array}{l}\text { Sira top- } \\
\text { lamı }\end{array}$ & $U$ & $p$ & $r$ \\
\hline $\begin{array}{l}\text { Diyet Öz Yeter- } \\
\text { lik Ölçeği }\end{array}$ & Bekar & 28 & 30.30 & 606.00 & 396.00 & $0.00^{*}$ & 0.32 \\
İkna Ölçeği & Evli & 72 & 51.00 & 3672.00 & & & \\
& Evkar & 28 & 31.95 & 639.00 & 429.00 & $0.01^{*}$ & 0.29 \\
\hline
\end{tabular}

${ }^{*} p<0.05$

Tablo 16 incelendiğinde katılımcıların diyet öz yeterlik inançları ölçeği ile ikna ölçeğinden elde ettikleri puan ortalamalarının medeni duruma göre anlamlı farklılık gösterdiği görülmektedir ( $U=396.00, U=429.00$; $\mathrm{p}<0.05)$. Sıra ortalamaları incelendiğinde hem diyet öz yeterlik inancı ölçeği hem de ikna ölçeğinde evli katılımcıların puanlarının bekârlardan daha yüksek olduğu görülmektedir. Bununla birlikte etki büyüklüğü değeri ise öz yeterlik ölçeği için 0.32 , ikna ölçeği için ise 0.29 olarak bulunmuştur. Elde edilen bu değere göre gruplar arası farkın orta düzeyde olduğu söylenebilir. Bu açıdan ele alındığında katılımcıların medeni durumun diyet öz yeterlik inançları ile diyete ikna durumlarını etkileyen önemli bir değişken olduğu söylenebilir.

\section{Tartışma ve Sonuç}

Bu bölüm araştırma içinde elde edilmiş bulgu ve yorumlara göre elde edilen sonuçlar ve öneriler için ayrılmıştır. Bu araştırma temel iki değişken üzerinden yürütülmüştür. Kişilerin demografik yapısının öz yeterlik inancı üzerinde bir etki farkı yaratıp yaratmadığı ve kişilerin diyete ikna edilmesi hususunda demografik yapının önemli olup olmadığı şeklindedir. Örneklemi oluşturan kişilerin durumları incelendiğinde en yüksek 
oranı üniversite mezunları oluşturduğu görülmektedir. Araştırmada diyet anlayışında eğitim durumunun önemli bir değişken olduğunu göstermiştir. Eğitim standardı yüksek olan kişilerin sağlıklı beslenme konusunda ikna edilmesinin daha kolay olduğu görülmektedir.

Sahada yapılan araştırma yaşın anlamlı bir farklılık gösterdiğini kanıtlamaktadır. Diyet özyeterlik açısından yaş almanın faktörü yüksektir. 2939 yaş arası en yüksek gruptadır. Yaş değişkenliği öz yeterlik inancı ve kişilerin diyete ikna edilmesinde önemli bir faktördür. Bu durumda genç orta yaş olarak adlandırılan 40-50 yaş grubun iknada da daha zorlandığ 1 görülmektedir. Bu da genç neslin yeni nesil mutfağı denediği, 40-50 yaş grubun ise daha gelenekselci tadlarda ve kötü alışkanlıklarda kalmakta ısrarcı olduklarını göstermektedir.

Semtler arasındaki fark açısından bakıldığında diyete ikna ve diyet öz yeterlik açısından Kadıköy/Fenerbahçe'de oturanların sıra ortalamalarının Maltepe/Yalı' da oturanlardan daha düşük olduğu görülmektedir. Etki büyüklükleri incelendiğinde ise diyet öz yeterlik ölçeğinde etki orta düzeyde, ikna ölçeğinde ise yüksek düzeydedir. Kadıköy/Fenerbahçe'de oturan katılımcılar ile Maltepe/Yalı'da oturan katılımcıların diyet öz yeterlik puanları arasındaki farkın orta düzeyde, diyete ikna durumları arasındaki farkın ise yüksek düzeyde olduğu görülmektedir. Maltepe ilçesinde daha toplulukçu aile profilinin ikamet etmesi, bireyselciliğin Kadıköy/ Fenerbahçe'de daha yaygın olması sonuçlara da yansımış durumdadir.

Araştırmada meslek gruplarının değişken olduğu, ev hanımlarının bu konuda daha etkin rol aldığı görülmektedir. Ev hanımlarının evde olmanın avantajını kullanarak diyet uygulamaya ağırlık verebildikleri anlaşılmaktadır.

Doğrudan bir özyeterlik ve ikna inancı göstergesinde medeni durumun avantajı fazlası ile anlaşılmaktadır. Evli olan grubun daha düzenli bir hayatı olması nedeni ile sağlıklı beslenme ve diyet konularına rahat yaklaşmaktadırlar. Bu durumda diyet özyeterlik inancı ve diyete ikna durumları da yüksek çıkmaktadır.

Olasılıksız örnekleme içinde kartopu yöntemi sayesinde sosyal sınıf açısından istatiksel anlamda geçerli karşılaştırmalar yapabilmek mümkün olmuş, araştırmanın sonuçları tümleşik bir hal alabilmiştir (Patton; 2005). 
Her iki semtte oturan kendi içinde homojen yapıda olan iki farklı örneklem grubu sayesinde sosyo ekonomik açıdan, aile yapısı açısından yeme alışkanlıkları belirlenmiştir. Kişinin sağlıklı beslenme açısından düşüncelerinin analizi demografik yapı içerisinde incelenmiştir.

Sonuç olarak, eğitim düzeyinin, yaşın, ikamet ettikleri semtin, mesleğin, medeni durumun öz yeterlik ve ikna açısından anlamlı farklılık gösterdiği anlaşılmıştır. İstikrarlı bir toplumsal yaşamı oluşturmak ve muhafaza etmek için sağlık önemli bir unsurdur. Toplumların gelişebilmesi, toplumun ilk grubu olan aile içerisinde beslenme ve bakım, sevgi ihtiyacı, duygusal gelişimi, psikolojik gelişimi için önemli bir konumdadır. Beslenme ve bakım doğumdan itibaren aile bireylerinin sağlık çalışanlarından, aile hekimlerinden, çocuk doktorlarından, endokrinologlardan veya diyetisyenlerden en azından biri ile doğru sağlık iletişimi çerçevesinde alması gereken hizmettir. Doğru yönlendirme ile diyete, sağlıklı beslenmeye teşvik edilen bireyler için önleyici ve koruyucu sağlık çerçevesi çizilebilecektir. Henüz hastalıklar çıkmadan kontrol altına alınması da sağlanmış olacaktır. Bu durum sadece bireye değil ülke ekonomisine de katkı sağlayacaktır. Bu bağlamda aile hekimliklerine diyetisyen ataması yapılması da önerilir. Araştırmanın, İstanbul ili diğer ilçeler veya İstanbul d1şındaki diğer illerde genelleştirilebilmesi ve daha geniş açılı bir örneklem üzerinde çalışılması koruyucu sağlık açısından daha vizyoner bakış açısı katacaktır. 


\title{
EXTENDED ABSTRACT
}

\section{An Effort for Motivation in Health Communication: An Analysis of Self-Efficacy Beliefs and Persuasion of People to Diet}

\author{
Ayşe Müge Yazgan \\ Marmara University
}

A preventive and protective health framework for individuals is likely to be established through effective health communication. Since the progress of scientific medicine, the necessity of communication with patients has been realized. The connection between the physician and the patient has been established. While the doctors are tending to explain more details in everyday language, the patients are more encouraged to ask questions about their health conditions.

By regarding healthy eating and healthy life understanding, rapid changing conditions today based on the concept and understanding of health have gained considerable importance. It is obvious that in literature only the persons who are ready to improve themselves are getting successful on healthy diet programs (Norris, Engelgau, and Narayan, 2001, s. 561-587). Besides being ready for a change, a persuasive and an empathetical communication style leads to significant changes in the cognitive structure of the person towards proper nutrition and the attitudes of the patients in case of illness. Many people wish to be convinced during decision-making. In this case, it is necessary to know the demographic structure of the patient well, to apply an appropriate diet program to the patient's thoughts, attitudes, and behaviors. As this study focuses on analysing the person's perceptions on healthy living eating, it aims to examine herself/himself from the perspective of her/his education, living conditions, and lifestyle. Evaluation of the patients' self-efficacy in terms of educational level, sociocultural and living conditions, and lifestyles in the process of persuasion in terms of knowing themselves and believing in their physicians is almost non-existent in the literature. For this reason, it 
is very vital to understand the success measure of persuasion and to obtain data to close the gap in the literature for the people who strive for healthy living.

Whether the demographic structure of the people has an impact on self-actualization and whether it is important in terms of persuading people to embrace a healthy diet are the two basic variables to be conducted in this research. The research design is on the quantitative method. The survey data is applied to 100 residents in İstanbul Kadıköy district Fenerbahçe neighbourhood and Maltepe district Yali neighbourhood. Frequency analysis is taken, and the results are entered into the 23.00 package program. In the demographic structure, it is seen that most of the participants $(64 \%)$ are university graduates. In total, $72 \%$ of the participants are married. According to the descriptive analysis obtained in the field, the highest scores should be 171 and 198. The scores of the participants were 135.25 and 182.09 as an average. In this sense, the examined impact coefficients are generally at an upper level with 0.54 and 0.41 points according to the education level. This situation shows that both dietary self-actualization and embracing a healthy diet persuasion of the study group are at a high level. The study has shown that educational status is an important variable in a healthy diet understanding. By self-efficacy scale means, it is observed that secondary school graduates are higher than university graduates with 89 points and higher than high school graduates with 64.50 points, compared to university graduates with 38.85 points. On the persuasion scale, participants with a master's / doctorate degree are at the top of the scale with 76.50 points. It seems that people with a high level of education are easier to be convinced about a healthy diet. Age variability is an important factor in self-efficacy beliefs and in persuading people to a healthy lifestyle. In this case, it is seen that the 40-50 age group, called the young middle age, has more difficulty in persuasion. This shows that the young generation tries the new generation cuisine, while the 40-50 age group insists on staying with more traditional tastes and unhealthy habits. Considering the differences between the districts, it is seen that the average rank of those living in Kadıköy / Fenerbahçe is lower than those living in Maltepe / Yali in terms of persuasion to diet and dietary self-efficacy. However, when the effect sizes are examined, it is found as 0.31 and 0.46 . Accordingly, the effect is moderate on the dietary self-efficacy scale and 
high on the persuasion scale. The fact that a more collectivist family profile resides in Maltepe district and individualistic culture is more widespread in Kadıköy / Fenerbahçe is reflected in the results. The study observes that the occupational groups are variable, and housewives take a more active role in this issue. The housewife group seems to be in the front phase with 87.94 points on the diet self-efficacy scale and 65.12 points on the persuasion scale. In the research, it is found out that they can concentrate on a healthy lifestyle by using the advantage of being at home. In the indicators of self-efficacy and persuasion belief, the advantage of marital status is understood well $(\mathrm{U}=396.00, \mathrm{U}=429.00 ; \mathrm{p}<0.05)$. When the average rank is examined, the married gets the higher score then the single. It is obviously seen that since the married group has a more regular life, they approach healthy nutrition and diet issues more comfortably than the single ones.

Consequently, it is realized that education level, age, district of residence, socio-cultural conditions, profession, and marital status differ significantly in terms of self-efficacy and persuasion. Healthy living is an important element in creating and maintaining a stable social life. It is in an important position for the development of societies, nutrition and selfcare, the need for love, emotional development, and psychological progress. Nutrition and care are the services that family members should receive from birth, within the framework of correct health communication with at least one of the healthcare professionals; dieticians, family physicians, pediatricians, or endocrinologists. A preventive and protective health framework can be drawn for individuals who are encouraged to maintain a healthy and balanced diet with correct guidance. That preventive health care is supported before diseases occur will be ensured. This situation will contribute to both the individual and the nation socioeconomically. In this context, it is also recommended to appoint a dietician to family physicians' polyclinics of each neighborhood. Generalizing the study to other districts in Istanbul or other provinces in Turkey and working on a wider sample will add a more visionary perspective in terms of preventive health. 


\section{Kaynakça/References}

Anık, C. (2006). Siyasal ikna. Ankara: Vadi Yayınları.

Bandura, A. (1977). Self-eficacy. Toward a unifying theoryof behavior change. Psychological Review, 84, 191-125.

Box, J. E. (2004). Placebos and the UK Medical reserach council and the consumer perspective. Science and Enginerring Ethics, 10(1), 98.

Çınarlı, İ. (2008). Sağlık iletişimi ve medya. Ankara: Nobel Yayınevi.

Dökmen, Ü. (2008). Sanatta ve günlük yaşamda iletişim çalışmaları ve empati. İstanbul: Remzi Kitabevi.

Grix, J. (2010). The foundations of research. London: Palgrave Mac Millan.

Karadoğan, E., (2003). Kişilererası iletişim sürecinde güven unsuru: Güven ve ikna ölçeği örneği. (Doktora Tezi). YÖK Tez Merkezi. (140923).

Krebs, J.R. and Davies, N.B. (1993). An introduction to behavioural ecology. [3 ${ }^{\text {rd }}$ Ed.] Oxford: Blackwell Scientific.

Marshall, M. (1996). Sampling for qualitative research. Family Practice, 13(6), 522-526.

Narula, U. (2006). Handbook of communication: Models, perspectives, strategies. Delhi: Atlantic.

Norris, S. L., Engelgau, M. M. and Narayan, V. K. (2001). Effectiveness of Self management training in Type-2 diabetes. Diabetes Care, 24(3), 561-587.

Okay, A. (2016). Să̆lık iletişimi. İstanbul: Derin yayınları.

Özerkan, Ş. ve İnceoğlu, Y. (1997). İletişimde etkileme süreci. İstanbul: Pan Yayınları.

Patton, M. (2005). Qualitative research. New York: John Wiley and Sons Ltd.

Patton, M. Q. (2014). Nitel araştırma ve değerlendirme yöntemleri (M.Bütün ve S.B. Demir, çev.). Ankara: Pegem Akademi.

Raithel, J., Dollinger, B. and Hormann, G. (2007). Einführung padagogik begriffe. Wiesbaden: VS Verlag Für Sozialwissenschaften.

Reddi, C. (2009). Effective public relations and media strategy. Delhi: PHI Learning.

Sabırcan, F. (2012). Sağlık iletişimi kapanyalarının davranış değişikliği oluşturmadaki rolü: Türkiye'de son 15 yılda yapılmış olan kampanayalardan örnekler çerçevesinde bir değerlendirme. (Yayınlanmamış Yüksek Lisans Tezi). İstanbul Üniversitesi Sosyal Bilimler Enstitüsü Halkla İlişkiler ve Tanıtım Anabilim Dalı,İstanbul. 
Schwartzer, R. and Fuchs, R. (1996). Self efficacy. The exercise of control; self efficacy and health behaviors; predicting health behavior. (M. Conner and P. Norman, Eds.), UK: Open University Press.

TDK Türk Dil Kurumu. Türk Dil Kurumu Sözlükleri. 3 Eylül 2020 tarihinde sozluk.gov.tr. adresinden alındı

Terris, M. (1995). The contributions of Henry E. sigerist to health service organization. . J Public Health Policy, 16(2),3-5.

Trost, S., Owen, N., Bauman, A., Sallis, J. F. and Brown, W. (2002). Correlates of adults' participation and physical activity: Review and update. Medicine Science and Sports Exercises, 34, 1996-2001.

United Nations World Health Organization Interim Commision. (1948). Summary Report on proceedings minutes and final acts of the international health conference. New York: WHO.

Yüksel, D. ve Sertel Berk, Ö. (2014). Sağlık psikolojisinde tedavi motivasyonu açısından diyet davranışları: Diyet öz yeterlilik inançları ölçeğinin geliştirilmesi ve psikometrik özellikleri. (Yayınlanmamış Yüksek Lisans Tezi). Okan Üniversitesi Sosyal Bilimler Enstitüsü, İstanbul.

\section{Kaynakça Bilgisi / Citation Information}

Yazgan, A. M. (2021). Sağlık iletişiminde motivasyona yönelik bir çaba: Öz yeterlilik inancının ve kişilerin diyete ikna edilmesi sürecinin analizi. OPUS- Uluslararası Toplum Araştırmaları Dergisi, 18(40), 2085-2115. DOI: 10.26466/opus.871362. 